\title{
The Impact of Cultural Diversity on the Academic Performance: A Study on Turkish Universities
}

\author{
Ercan Turgut \\ Correspondence: Ercan Turgut, Department of Business Administration, Turkish Military Academy, Bakanliklar, 06654, \\ Ankara, Turkey. Tel: 90-312-417-5190. E-mail: eturgut@kho.edu.tr
}

Received: March 3, 2016

doi:10.5539/ibr.v9n5p135

\author{
Accepted: March 22, 2016 \\ Online Published: March 29, 2016 \\ URL: http://dx.doi.org/10.5539/ibr.v9n5p135
}

\begin{abstract}
Universities as science production centers are institutions that bring diverse information together. It is noteworthy that no longer these institutions have more international and heterogeneous structures. Qualified foreign academicians with the educational culture of a different country get universities stronger with these differences and knowledge, and improve the universities' academic performance. Considering this idea in this research the effect of the number of foreign academicians to the academic performance of universities is investigated. For this purpose, the effect and correlation between performance rates of 130 universities of Turkey and the number of the foreign academicians, which is evaluated by University Ranking by Academic Performance Research Laboratory (URAP), have been revealed with correlation and regression analysis. As a consequence, a positive and weak relationship was determined between the number of foreign academicians and performance. Also the number of the foreign instructors affects the performance of the universities positively.
\end{abstract}

Keywords: University internationalization, cultural diversity, university performance

\section{Introduction}

The heterogeneity and internationalization of the universities gradually increase with the support of university administrations and the state (Park, 2009). For instance The Scientific and Technological Research Council of Turkey (TUBITAK) offers special support programs for researchers from abroad to do research in Turkey. Due to the heterogeneity and internationalization of the universities, academicians wtih different research culture can join to these universities. When it is considered that academicians have limited sources and capacities and have the ability to improve their capacity by contacting other researchers (Abbasi\&Jaafari,2013) it will be beneficial to have foreign academicians in this network (Barjak \& Robinson, 2008). Thus, there is a need for collaboration between academicians in the extraction of new information (Demsetz, 1991).

Academic collaboration will result in academic publishing and so affects the performance of the universities in a positive way. From this point of view, in this research the effect of number of foreign academicians on the performance of the universities was examined. The fact that researches on diversity primarily focus commercial enterprises and lack of such research on universities' performance add to the value of this research. In addition, using the data from an independent evaluation organization- URAP and studying on numerous universities is the strong side of this research. As a result of this research the contribution was provided to the literature about cultural differences on universities. In addition, the lack of such a study on the universities of Turkey offer added value to the study. It is believed that the results of the study will provide guidance to establish the academic staff structures of universities.

\section{Conceptual Framework and Hypotheses}

\subsection{Cultural Diversity-performance Relationship}

With regard to employment structure, one tendency, which have begun at the late 1990s and effective for the business life of the 21st century, is increasing diversity phenomena (Higgs, 1996; Lavaty and Kleiner, 2001). Diversitiy expresses a heterotaxic structure that includes the individuals with different group characteristics in the same social system (Fleury, 1999). If an orgainzation consists of different employees according to workforce profile, demographic, and other characteristics, then it is considered to have a diver structure. The criteria of this diversification includes race, ethnicity, gender, age, physical and mental competence, beliefs, culture, economic class, sexual preference, etc (Dessler, 1998; Galagan, 1991). Although different results have been found on some studies about diversity (Chatman \& O'Reilly, 2004; Williams \& O'Reilly, 1998) usually it is indicated that diversity affects organizational performance in a possitive 
way (Milliken \& Martins, 1996; Simons, Pelled, \& Smith, 1999). The diversity of the group is believed to contribute to the creativity by bringing different perspectives. Also thanks to the diversity, different network ties of group members expand the structure of the group's total network (Ely \& Thomas, 2001; Page, 2007). Indeed, Cummings \& Cross (2003) stated that sharing external information that arises from individualsexternal professional network would increase the performance of the group. Diversity facilitates the integration of different specialties, it contributes to the successful development of a project and shortens the development time of a new product (Cummings, 2004; Eisenhardt \& Tabrizi, 1995; Griffin \& Hauser, 1992; Pinto, Pinto, \& Prescott, 1993). For this reason, academicians with different abilities, skills, experience and knowledge should work together in a cohesive team (McFadyen, Semadeni, \& Cannella, 2009). It is believed that the performance will increase through the internal and external sharing of information within the groups with diversities (Monge, Rothman, Eisenberg, Miller, \& Kirste, 1985).

Daft (2003:440) examines the diversity in the form of a binary distinction as "base dimensions" and "secondary dimensions". According to the author, basic dimensions exercise influence over individual throughout their entire life or express innate differences. Basic dimensions include race, ethnicity, gender, physical or mental competency of individuals, and factors such as self-image and the core elements that can shape worldview. Secondary dimesions are the qualifications that indivduals acquire throughout their lives, in other words, acquired later in their life and changeable qualifications. Cultural diversity in organizations is included in the scope of secondary dimesion of Daft (2003) and has important effects on individuals' attitudes, behaviour, and perceptions. Individual or group-specific properties arising from cultural differences in organisations may affect employees' sense of identity. Moreover the way of perceiving the others and management style, patterns of organizational behaviour and differences in communication patterns are mostly rooted in cultural influences (Frey-Ridgway, 1997; Karoc-Kakabadse \& Kouzmin, 2001; Mwaura, Sutton \& Roberts, 1998).

When these dimensions of diversity are expressed at two levels as superficial and deep, superficial diversity contains biological features that provide a strong foundation for social categorization and sightful superficial features (Jackson, Stone, \& Alvarez, 1993). Besides, there are differences that cannot be noticed immediately at deep-level heterogeneity (Harrison et al., 2002). Deep-level diversity contains the differences between group members' attitudes, norms and beliefs. It is indicated that this diversity have a positive effect on the performance (Larson, 2007; Mitchell, Nicholas, \& Boyle, 2009; Tyran \& Gibson, 2008). Because of the fact that there are differences among employees from different nationalities in terms of worldview, behavior patterns, values, and norms, the majority of the employees of different nationalities refers to deep-level heterogeneity as cultural diversity (Hambrick, Davison, Snell, \& Snow, 1998; Jackson et al., 1995). In line with the paradigm of diversity, it is stated that group members of different nationalities have a positive effect on group performance (Ely \& Thomas, 2001; Hambrick et al., 1998; Maznevski, 1994; Oosterhof et al., 2009). Furthermore considering the internationalisation of today's universities, group members with different national backgrounds will be benefical for group performance. The benefit will not be limited to the konwledge and experience of academicians but also include language skills (Lauring \& Selmer, 2010). Moreover, previous network ties of foreign academicians would contribute to the available resources, information, and the publication rate

Studies on the effects of cultural diversity began in the 1960s. Hoffman \& Maier (1961) have stated that culturally heterogeneous groups found better solutions than homogeneous ones. Similarly, Triandis, Hall and Ewen (1965) said that heterogeneous groups were more creative than homogeneous groups at the same skill level. Concordantly Watson, Kumar, and Michael (1993) have found that heterogeneous groups were more successful in problem solving and finding solutions than homogeneous groups over time. On the other hand, Feldman, Sam, McDonald, \& Bechtel, (1980) have mentioned that working together for heterogeneous groups were more challenging and stressful. However, there are many studies demonstrate that such differences will lead to creativity and positive outcomes (Epton, Payne, \& Pearson, 1985; Jackson et al., 1995; Jehn et al., 1999; McLeod \& Lobe, 1992). Lillis \& Curry (2006) have indicated that academicians living in non-Enlish speaking countries work with foreigners who are good at English skills. Barjak \& Robinson (2008) have found that academic research teams at the middle level cultural diversity are more successful. Looking at 16 sections of three universities in Denmark, Lauring and Selmer (2010) found that cultural diversity has a positive influence on satisfaction and performance. More relevant to this research, Mamiseishvili and Rosser, (2010) have found that international diversity had a positive impact on performance. Based on the theories and studies above, the following hypothesis has been developed.

Hypothesis: Cultural diversity (the number of foreign academicians) has a positive effect on the academic performance of a university.

\subsection{Status of Universities in Turkey}

The first university in Turkey in the Republican period, was established in 1933, ten years later than the founding of the Republic. The University of the Ottoman which means "Darülfünun" eliminated and instead "Istanbul University" was 
established in accordance with the law no.2252 that enacted on 31 May 1933 (Dölen, 2009; İhsanoğlu, 2010). In 1944, Istanbul Technical University was established in Istanbul. In 1946 Ankara University was established in Ankara. By the year 1982, the number of universities has increased to 27. Up until the establishment of Bilkent University in 1985as a private, all of the universities were public universities. Although only 29 universities have been established in 59 years until 1992, 23 universities have been founded in one year (1992) with the government decision. Until 2006 no public university has been establishet but 22 private universities have been founded from 1996 to2005. In 2006 and 2007, again in accordance with the 'a university for each city' decision of the government, 32 universities were founded in various cities. Currently 193 universities continue their operation in till 2015. Hence 109 of these universites are public universities, and 84 of them are private universities. The number of universities in Turkey by years could be observed in Figure 1. As seen in the chart, in recent years there has been a marked increase in the number of private universities and the gap between the number of public and private universities has reduced. With the opening of new public and private universities new university students have been provided the opportunity to choose between universities. This makes it difficult for the university to attract the best students. This situation is considered as an indicator of the competition between universities that increase day by day.

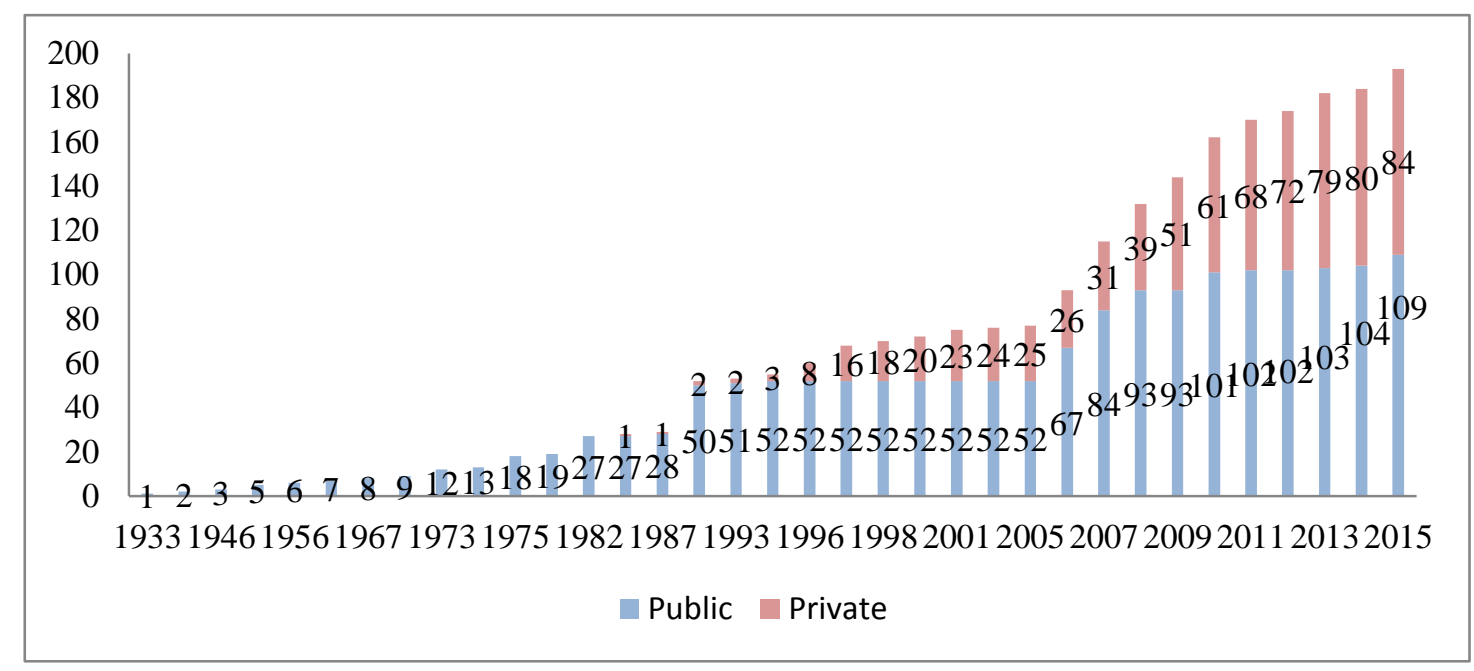

Figure 1. The Number of Public and Private Universities in Turkey by Years

Since the early years of the Republic foreign academicians have been considered important. Thus the Turkish historian, Stanford Shaw stated that Atatürk and Hasan Âli Yücel, Minister of National Education, has led to significant development of scientific institutions and universities in Turkey by bringing hundreds of people who are exported from education and science by Hitler to Turkey. The numbers of foreign teaching staff by years are presented in Figure 2 .

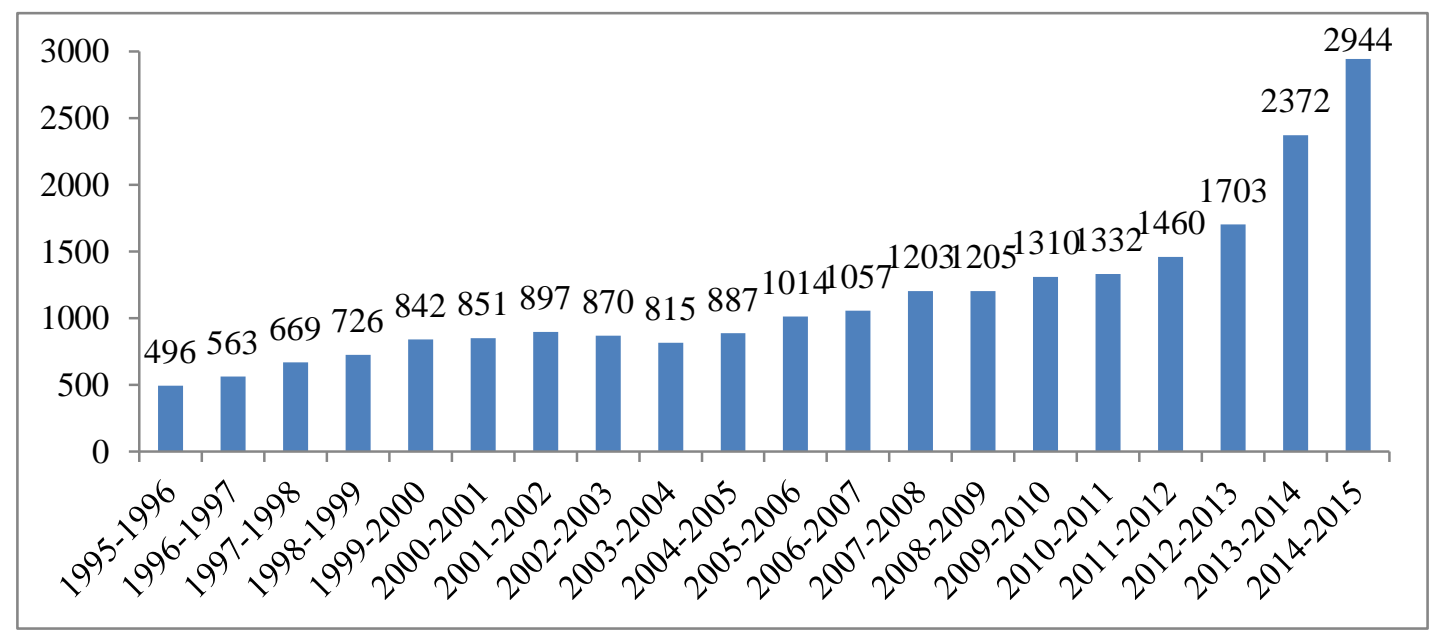

Figure 2. The Numbers of Foreign Academicians in Turkey, by years

\subsection{Evaluation of Academic Performances of the Universities and the Place of Turkish Universities in the World}

There are quite a number of organizations that evaluates universities' academic performance publish ranking reports. 
Academic Ranking of World Universities (ARWU) which is also known as Shanghai Ranking origin of China, Center for World University Rankings origin of Saudi Arabia, LEIDEN origin of Netherlands, WEBOMETRICS origin of Spain, and Times Higher Education World University Rankings (THE) and QS origin of the United Kingdom are among these type of organizatons. These rankings could be decisive for students and academicians while choosing a university to study or work. Research supporting organizations view university's rank in the world as an evaluation criteria to support the $\mathrm{PhD}$ and post-doc researches. For example, in Turkey, one criteria of TUBITAK, a research supporting organizaton, is the academic ranking of the university.. For these reasons, being among the top ranks is an important feature for universities.

Similar to the organization mentioned above, the research laboratory URAP (University ranking by academic performance) was founded within the structure of Informatics Institute of Middle East Technical University in 2009. The aim of URAP is to develop scientific methods for evaluating higher education institutions according to their academic achievements, and to share the results of the researches to public opinion. As the products of these researches 2000 world universities were ranged by URAP World Ranking, and more than 100 universities in Turkey were ranged by URAP Turkey Ranking according to various criterias of academic performances. URAP does not aim to categorise universities as good and bad. The goal of URAP is provide to compare universities' own academic performance with other universities and to be aware of improvable aspects according to specified criterias with the data obtained as a result of researches. According to URAP world rankings, in the academic year 2014-2015 ranking; there are 5 Turkish universities in the top 500, 19 Turkish universities in the top 1000 and 76 Turkish universities in the top 2000. According to the other research institutions mentioned above, many Turkish universities rank among the top 500 to 1000 in the academic year 2014-2015. As a result of this situation it has been thought that Turkish universities have mid-level position among the world universities and some universities take place among the best universities in the world. URAP have used the data of Web of Science/In Cites and the council of higher education (YOK) in 2015-2016 university assessment. Nine indicators of URAP Turkey Ranking that are used for ranking universities are given at Table 1.

Table 1. Indicators used by the URAP Turkey Ranking

\begin{tabular}{|c|c|c|c|c|}
\hline No & Indicator & Aim & Source & Statement \\
\hline 1 & The Number of Articles & Research & InCites & $\begin{array}{l}\text { The Number of Articles included in the scan of SCI, } \\
\text { SSCI and AHCI in } 2014\end{array}$ \\
\hline 2 & $\begin{array}{l}\text { The Number of Articles per } \\
\text { Lecturer }\end{array}$ & Research & $\begin{array}{l}\text { InCites and } \\
\text { YOK }\end{array}$ & $\begin{array}{l}\text { The Number of Articles included in the scan of SCI, } \\
\text { SSCI and AHCI in } 2014 \text { / } \\
\text { The Number of Lecturers in } 2014\end{array}$ \\
\hline 3 & The Number of Citations & Research & InCites & $\begin{array}{l}\text { The total number of citations received between the } \\
\text { years } 2012-2014\end{array}$ \\
\hline 4 & $\begin{array}{l}\text { The Number of Citations per } \\
\text { Lecturer }\end{array}$ & Research & $\begin{array}{l}\text { InCites and } \\
\text { YOK }\end{array}$ & $\begin{array}{l}\text { The total number of citations received between the } \\
\text { years } 2012-2014 \text { / The Number of Lecturers in } 2014\end{array}$ \\
\hline 5 & $\begin{array}{l}\text { The Total Number of Scientific } \\
\text { Documents }\end{array}$ & Research & InCites & $\begin{array}{l}\text { The total number of publication, notification, etc made } \\
\text { between the years } 2012-2014\end{array}$ \\
\hline 6 & $\begin{array}{l}\text { The Number of Total Scientific } \\
\text { Documents per Lecturer }\end{array}$ & Research & $\begin{array}{l}\text { InCites and } \\
\text { YOK }\end{array}$ & $\begin{array}{l}\text { The total number of publication, notification, etc made } \\
\text { between the years 2012-2014 / The Number of } \\
\text { Lecturers in } 2014\end{array}$ \\
\hline 7 & The Number of PhD Students & $\begin{array}{l}\text { Education and } \\
\text { Research }\end{array}$ & YOK & $\begin{array}{l}\text { The number of } \mathrm{PhD} \text { students in the academic year } \\
2014-2015\end{array}$ \\
\hline 8 & The Rate of PhD Students & $\begin{array}{l}\text { Education and } \\
\text { Research }\end{array}$ & YOK & $\begin{array}{l}\text { The number of } \mathrm{PhD} \text { students in the academic year } \\
2014-2015 \text { /the total number of students in the same } \\
\text { period }\end{array}$ \\
\hline 9 & $\begin{array}{l}\text { The Number Of Students per } \\
\text { Lecturer }\end{array}$ & Education & YOK & $\begin{array}{l}\text { The total number of students in the academic year } \\
\text { 2014-2015 / The Number of Lecturers in } 2014\end{array}$ \\
\hline
\end{tabular}

Resource: http://tr.urapcenter.org/2015/2015-2016_Turkiye_Siralamasi_26_EKIM_2015.pdf

1st, 3rd and 5th indicators given in chart are in favor of major universities and it should not be ignored that these institutions contribute to world science more than others. It is natural to get a high score due to these contributions. 2nd, 4th and 6th indicators in the chart, measure productivity per person regardless of the size of the university. Thus, the major universities has a chance to receive a high score thanks to the total output and minor ones takes scores thanks to their productivity. When the continuity of the performance have been measured by 3rd, 4th, 5th, and 6th indicators, actuality of performance have been evaluated by the other indicators. Moreover the endevour of the universities that have limited articles in magazines listed in the indexes of SCI, SSCI and AHCI, but have many scientific works in conferences, book chapters, etc. is evaluated by the 5th and 6th indicators. The nine indicators used in the ranking has equal weight percentages. 


\section{Methodology}

In this study the subjects, whether there is a correlation between the number of foreign staff and the academic performances of the universities in Turkey, and in what ways the number of foreign staff affects the academic performances were aimed to investigate. For this purpose, data on the number of foreign academics of universities in Turkey were obtained from the official website of the council of higher education (YOK) (http://www.yok.gov.tr/) and they were transferred to the Excel spreadsheet. Then data on the academic performance of the universities in Turkey were obtained from the website of University Ranking by Academic Performance Research Laboratory (URAP) (http://tr.urapcenter.org/2015/2015_t9.php) and they were transferred to another Excel spreadsheet. Then the data in these two tables by matching with the VLOOKUP command in Excel on the basis of the University was made into a single Excel spreadsheet. Afterwards this generated Excel spreadsheet were transferred to Spss, and correlation and regression analyses were conducted through this program.

In the preparation of the data set, for the numbers of foreign academics of universities data of 2013 and for the University performance data of 2014 were used. Considering the process of article publication which takes approximately one year, the previous year's data were used for the numbers of foreign academics. An example of a data set is given in Table 2. The complete set of data is in the appendix.

Table 2. Example of a Data Set

\begin{tabular}{lccc}
\hline & University & Article (1) & Citation \\
& & $(2)$ & $\begin{array}{c}\text { Foreign Scholars } \\
(3)\end{array}$ \\
\hline Middle East Technical Uniıversity & 167.35 & 188.6 & 45 \\
Hacettepe University & 155.16 & 159.88 & 32 \\
Istanbul University & 153.51 & 154.97 & 64 \\
Bilkent University & 169.62 & 187.63 & 179 \\
\hline
\end{tabular}

The second column which is shown as number (1) at the Table 2 has been called as The Article Point. This column has been calculated as the number of articles point in $2014+$ the number of articles point in 2014 per lecturer.

The third column in the chart is named as number (2) and it have been termed as Citation Point. It refers to the number of citations (given to the articles published between the years 2012-2014) point + the number of articles (given to the articles published between the years 2012-2014) point in 2014 per lecturer.

Finally, the 4th column, the column number (3) refers to the number of foreign scholars of the universities in 2013.

\section{Findings}

Number (1) and (2) column data in the data set refer the performance indicators of the universities and the column number (3) refers the number of foreign staff. Correlation and regression analyses were made between columns number (3), (1) and (2) in the study. The normality test had been conducted before analyses and it was found that the dependent variables have normal distribution. Test results and histogram diagrams related to the normality test is presented in the appendix. As a result of the analysis, the results of the correlation analysis and the values of the averages and the standard deviation presented in the Table 3.

Table 3. Mean, Standard Deviation and Correlations Values

\begin{tabular}{|c|c|c|c|c|}
\hline & Mean & $\begin{array}{c}\text { S. } \\
\text { Dev. }\end{array}$ & $\begin{array}{c}1 \\
\text { Article } \\
\end{array}$ & $\begin{array}{c}2 \\
\text { Citation } \\
\end{array}$ \\
\hline 1. Article & 92,3436 & 36,13480 & & \\
\hline 2. Citation & 94,9539 & 36,91187 &, $843^{* *}$ & \\
\hline 3. Foreign Scholars & 14,8154 & 23,17670 &, $344 * *$ &, $393 * *$ \\
\hline
\end{tabular}

As seen from Table 3, there is positive, meaningful, and just under the middle level relationship between the numbers of foreign academics in universities and the academic performance computed according to the articles. In the same way there is positive, meaningful and just under the middle level relationship between the number of foreign academicians and academic performance that is calculated by citations. The relationship, which is based on the number of citations is a little more high than the number of articles. It is considered that the previous works of foreign scholars is a factor.

Table4. Regression Analysis Results of Foreign Scholars on Academic Performance (Article and Citation)

\begin{tabular}{lcccccc}
\hline & \multicolumn{3}{c}{ Article } & \multicolumn{3}{c}{ Citation } \\
\cline { 2 - 7 } & Beta & $t$ & Sig & Beta & $t$ & Sig \\
\hline Foreign Scholars & .344 & 4.149 & .000 & .393 & 4.835 & .000 \\
Adjusted $R^{2}$ & .112 & & & .148 & & \\
$F$ ratio & 17.213 & & & 23.374 & & \\
$F$ ratio $P$ & .000 & & & .000 & & \\
\hline
\end{tabular}


According to the results of regression analysis (Table 4), the number of foreign academicians causes $11,2 \%$ of the change in performance according to the article points. Moreover the number of foreign academicians causes $14,8 \%$ of the change in performance according to the citation point of universities. In this case, it was determined that the hypothesis established in the research was supported by the result of the regression of analysis.

\section{Discussion and Conclusion}

With the increase of transportation and communication facilities, accessing to goods and services has become easier for customers. Thus this case have increased customers' opportunities to obtain information about goods and services and has provided the opportunity to compare the goods and services with each other. Similarly a serious competition has emerged among universities in terms of including the best students in their structure and providing research funds and state support. In this environment, it is considered academical performance that published by independent international organizations create a perception about the quality of the universities. It can be thought that this perception might be played an active role to attract academicians and researchers.

The presence of foreign academicians within the university is considered to be beneficial for contribution of these scholars with their knowledge, skills, and infrastructures. Hence as a result of the study, number of foreign academicians of universities has a positive impact on academial performances in terms of articles and citations of universities have been found. This situation has enabled to reach a judgment that the hypothesis established in this research has been supported. This situation coincides with the previous studies (Mamiseishvili \& Rosser, 2010; Lauring \& Selmer, 2010).

As a result, cultural diversity of the academicans in a university has a positive influence on performance. From the light of this result, the development of human resources practices related to presence of foreign academicians at the universities will be positive in terms of improving the performance of the university. The language advantages of foreign academicians will be beneficial to overcome the language problems of articles. It is considered that examining especially English articles by more people provides to increase the number of citations and thus to increase the citation performance of the university. Academic qualifications of foreign scholars have a positive effect on the studies. Moreover the networks that come from previous working and education places of the foreign academicians, can contribute to doing researches and publish them.

In addition to all these benefits, to increase the number of foreign academicians too much in universities could result in universities alienated from the country and society and give harm to the universities feature of being institutions that seeking solutions to country's problems. For this reason, it is thought that foreign academics should be evaluated as a catalyst.

\section{References}

Abbasi, A., \& Jaafari, A. (2013). Research impact and scholars' geographical diversity. Journal of Informetrics, 7, 683692. http://dx.doi.org/10.1016/j.joi.2013.04.004

Barjak, F., \& Robinson, S. (2008). International collaboration, mobility and team diversity in the life sciences: Impact on research performance. Social Geography, 3(1), 23-38.

Chatman, J., \& O'Reilly, C. (2004). Asymmetric effects of work group demography on men's and women's responses to work group composition. Academy of Management Journal, 47(2), 193-208.

Cummings, J., \& Cross, R. (2003). Structural properties of work groups and their consequences for performance. Social Networks, 25(3), 197-210. http://dx.doi.org/10.1016/S0378-8733(02)00049-7

Cummings, J. N. (2004). Work groups, structural diversity, and knowledge sharing in a global organization. Management Science, 50(3), 352-364. http://dx.doi.org/10.1287/mnsc.1030.0134

Daft, R. L. (2003). Management, 6th. Ed., London, Thomson Learning.

Demsetz, H. (1991). The theory of the firm revisited. In O. E. Williamson, S. G. Winter, \& R. H. Coase (Eds.), The nature of the firm: Origins, evolution, anddevelopment (pp. 159-179). New York: Oxford University Press.

Dessler, G. (1998). Management, International Ed., New Jersey, Prentice-Hall, Inc.

Dölen, E. (2009).Türkiye Üniversite Tarihi, Cilt 1, Osmanlı Döneminde Darülfünun (1863-1922), İstanbul Bilgi Üniversitesi Yayınları, İstanbul

Eisenhardt, K., \& Tabrizi, B. N. (1995). Accelerating adaptive processes: Product innovation in the global computer industry. Administrative Science Quarterly, 40(1). http://dx.doi.org/10.2307/2393701

Ely, R. J., \& Thomas, D. A. (2001). Cultural diversity at work: The effects of diversity perspectives on work group processes and outcomes. Administrative Science Quarterly, 46(2), 229-273. http://dx.doi.org/10.2307/2667087 
Epton, S. R., Payne, R. L., \& Pearson, A. W. (1985). Contextual issues in managing cross-disciplinary research. In B. W. Mar, W. T. Newell, \& B. O. Saxberg (Eds.), Managing high technology: An interdisciplinary perspective. Amsterdam: Elsevier.

Fleury, M. T. (1999). The Management of Culture Diversity: Lessons from Brazilian Companies, Industrial Management \& Data Systems, 99(3), 109-114. http://dx.doi.org/10.1108/02635579910252635

Frey-Ridgw A. Y. S. (1997). The Cultural Dimension of International Business. Collection Building, 16(1), 12-23. http://dx.doi.org/10.1108/01604959710156925

Feldman, J. M., Sam, I. A., McDonald, W. F., \& Bechtel, G. G. (1980). Work outcome preference and evaluation: A study of three ethnic groups. Journal of Cross-Cultural Psychology, 11, 444-468. http://dx.doi.org/10.1177/0022022180114004

Galagan, P. A. (1991). Tapping the Power of a Diverse Workforce. Training \&Development, 45(3), 1-9.

Griffin, A., \& Hauser, J. R. (1992). Patterns of communication among marketing, engineering and manufacturing A comparison between two new product teams. Management Science, 38(3), 360-373. http://dx.doi.org/10.1287/mnsc.38.3.360

Hambrick, D. C., Davison, S. C., Snell, S. A., \& Snow, C. C. (1998). When groups consist of multiple nationalities. Organization Studies, 19(2), 181-206. . http://dx.doi.org/10.1080/09585192.2014.949819

Harrison, D. A., Price, K. H., Gavin, J. H., \& Florey, A. T. (2002). Time, teams, and task performance: Changing effects of surface- and deep-level diversity on group functioning. Academy of Management Journal, 45, 1029-1045. http://dx.doi.org/10.2307/3069328

Higgs, M. (1996). Overcoming the Problems of Cultural Differences to Establish Succes for International Management Teams. Team Performance Management:An International Journal, 2(1), 36-43.

Hoffman, L., \& Maier, N. (1961). Quality and acceptance of problem solutions by members of homogeneous and heterogeneous groups. Journal of Abnormal and Social Psychology 62, 401-407. http://dx.doi.org/10.1037/h0044025

İhsanoğlu, E. (2010). Darülfünun: Osmanlı’da Kültürel Modernleşmenin Odağı, İstanbul: İslam Tarih, Sanat ve Kültür Araştırma Merkezi

Larson, J. R. (2007). Deep diversity and strong synergy: Modeling the impact of variability in members' problem-solving strategies on group problem-solving performance. Small Group Research, 38(3), 413-436.

Lauring, J., \& Selmer J. (2010). Is university internationalization bad for performance? Examining two different types of diversity. International Journal of Educational Research 49, 161-171. http://dx.doi.org/10.1016/j.ijer.2011.02.002

Lavaty, S. B., \& Kleıner, H. (2001). Managing and Understanding the French Employee. Management Research News, 24(3/4), 45- 48. http://dx.doi.org/10.1108/01409170110782603

Lillis, T., \& Curry, M. J. (2006). Professional academic writing by multilingual scholars: Interactions with literacy brokers in the production of English-medium texts. Written Communication, 23(1), 3-35. http://dx.doi.org/10.1177/0741088305283754

Karoc-Kakabadse, N., Karoc-Kakabadse, A., \& Kouzmin A. (2001). Low-and High- Context Communication Patterns: Towards Mapping Cross-Cultural Encounters. Cross Cultural Management, 8(2), 3-24. http://dx.doi.org/10.1108/13527600110797218

Jackson, S. E., Stone, V. K., \& Alvarez, E. B. (1993). Socialization amidst diversity: Impact of demographics on work team oldtimers and newcomers. In L. L.Cummings \& B. M. Staw (Eds.), Research in organizational behavior (pp. 45-109). Greenwich: JAI Press.

Jackson, S. E., May, K. E., \& Whitney, K. (1995). Understanding the dynamics of diversity in decision-making teams. In R. A. Guzzo \& E. Salas (Eds.), Team decision-making effectiveness in organizations (pp. 204-261). San Francisco: Jossey-Bass.

Jehn, K. A., Neale, M., \& Northcraft, G. (1999). Why differences make a difference: A field study of diversity, conflict, and performance in workgroups. Administrative Science Quarterly, 44(4), 741-763. http://dx.doi.org/10.2307/2667054

Maznevski, M. L. (1994), Synergy and Performance in Multicultural Teams, unpublished Ph.D. dissertation, The University of Western Ontario. 
Mamiseishvili, K., \& Rosser, V. J. (2010). International and citizen faculty in the United States: An examination of their productivity at research universities. Research in Higher Education, 51(1), 88-107. http://dx.doi.org/10.1007/S11162-009-9145-8

McFadyen, M., Semadeni, M., \& Cannella, A. A. (2009). Value of strong ties to disconnected others: Examining knowledge creation in biomedicine. Organization Science, 20(3), 552-564. http://dx.doi.org/10.1287/orsc.1080.0388

McLeod, P. L., \& Lobe, S. A. (1992). The effects of ethnic diversity on idea generation in small groups, Academy of Management Annual Meeting Best Papers Proceedings, 227-231.

Milliken, F. J., \& Martins, L. L. (1996). Searching for common threads: Understanding the multiple effects of diversity in organizational groups. Academy of Management Review, 21, 402-433. http://dx.doi.org/10.5465/AMR.1996.9605060217

Mitchell, R., Nicholas, S., \& Boyle, B. (2009). The role of openness to cognitive diversity and group processes in knowledge creation. Small Group Research, 40(5), 535-554. http://dx.doi.org/10.1177/1046496409338302

Monge, P., Rothman, L., Eisenberg, E., Miller, K., \& Kirste, K. (1985). The dynamics of organizational proximity. Management Science, 31(9), 1129-1141. http://dx.doi.org/10.1287/mnsc.31.9.1129.

Mwaura, G., Sutton, J., \& Roberts D. (1998). Corporate and National Culture-An Irreconcilable Dilemma for the Hospitality Manager? International Journal of Contemporary Hospitality Management, 10(6), 212-220. http://dx.doi.org/10.1108/09596119810232211

Oosterhof, A., Van der Vegt, G. S., Van de Vliert, E., \& Sanders, K. (2009). Valuing skill differences: Perceived skill complementarity and dyadic helping behavior inteams. Group and Organization Management, 34(5), 536-562. http://dx.doi.org/10.1177/1059601108331239

Page, S. E. (2007). Making the difference: Applying a logic of diversity. Academy of Management Perspectives, 21(4), 6-21. http://dx.doi.org/10.5465/AMP.2007.27895335

Park, J. J. (2009). Are we satisfied? A look at student satisfaction with diversity at traditionally white institutions. The Review of Higher Education, 32(3), 291-320. http://dx.doi.org/10.1353/rhe.0.0071

Pinto, M. B., Pinto, J. K., \& Prescott, J. E. (1993). Antecedents and consequences of project team cross-functional cooperation. Management Science, 39(10), 1281-1297. http://dx.doi.org/10.1287/mnsc.39.10.1281

Simons, T., Pelled, L. H., \& Smith, K. A. (1999). Making use of difference: Diversity, debate, and decision comprehensiveness in top management teams. Academy of Management Journal, 42(6), 662-673. http://dx.doi.org/10.2307/256987

Stanford, S. (1992). Turkey and the Holocaust: Turkey's role in rescuing Turkish and European Jewry from Nazi persecution, 1933-1945, Macmillan, London ve New York University Press,

Watson, W., Kumar, K., \& Michaelsen, L. K. (1993). Cultural diversity's impact on interaction process and performance: Comparing homogeneous and diverse task groups. Academy of Management Journal, 36, 560-602. http://dx.doi.org/10.2307/256593

Williams, K., \& O’Reilly, C. A. (1998). Demography and diversity: A review of 40 years of research. In B. Staw \& R. Sutton (Eds.), Research in Organizational Behavior (pp. 77-140). Greenwich: JAI Press.

Triandis, N. C., Hall, E. R., \& Ewen, R. B. (1965). Member homogeneity and dyadic creativity. Human Relations, 18, 33-54. http://dx.doi.org/10.1177/001872676501800104

Tyran, K. L., \& Gibson, C. B. (2008). Is what you see, what you get? The relationship among surface- and deep-level heterogeneity characteristics, group efficacy, and team reputation. Group and Organization Management, 33, 4676. http://dx.doi.org/10.1177/1059601106287111 


\section{Appendix A}

Table A1. Data Set

\begin{tabular}{|c|c|c|c|}
\hline University & Article (1) & Citation (2) & $\begin{array}{c}\text { Foreign } \\
\text { Scholars (3) }\end{array}$ \\
\hline Middle East Technical University & 167,35 & 188,66 & 45 \\
\hline Hacettepe University & 155,16 & 159,88 & 32 \\
\hline Istanbul University & 153,51 & 154,97 & 64 \\
\hline Bilkent University & 169,62 & 187,63 & 179 \\
\hline Ankara University & 146,15 & 141,29 & 6 \\
\hline Istanbul Teknik University & 150,92 & 149,33 & 48 \\
\hline Gebze Institute Of Technology & 139,72 & 164,13 & 9 \\
\hline Ege University & 147,15 & 145,92 & 3 \\
\hline Gazi University & 148,95 & 136,87 & 9 \\
\hline Sabanci University & 152,49 & 166,62 & 41 \\
\hline Koc University & 138,53 & 170,23 & 83 \\
\hline Bogazici University & 143,74 & 129,92 & 70 \\
\hline Ataturk University & 130,41 & 131,28 & 17 \\
\hline Yildiz Teknik University & 136,74 & 126,29 & 13 \\
\hline Erciyes University & 136,77 & 142,78 & 45 \\
\hline Izmir Institute Of Technology & 135,58 & 110,16 & 15 \\
\hline Marmara University & 115,27 & 131,15 & 49 \\
\hline Selcuk University & 126,4 & 131,24 & 14 \\
\hline Dokuz Eylul University & 124,27 & 128,46 & 25 \\
\hline Karadeniz Teknik University & 129,99 & 129,02 & 10 \\
\hline Baskent University & 122,05 & 113,19 & 19 \\
\hline Cukurova University & 124,15 & 121,18 & 0 \\
\hline Akdeniz University & 124,37 & 123,24 & 3 \\
\hline Ondokuz Mayis University & 126,05 & 121,09 & 1 \\
\hline Suleyman Demirel University & 126,06 & 122,21 & 0 \\
\hline Dogus University & 146,26 & 113,67 & 12 \\
\hline Dicle University & 126,63 & 117,76 & 0 \\
\hline Atilim University & 116,05 & 161,75 & 17 \\
\hline Uludag University & 119,04 & 120,83 & 15 \\
\hline Firat University & 120,11 & 126,84 & 0 \\
\hline Fatih University & 109,91 & 127,03 & 78 \\
\hline Ozyegin University & 112,11 & 169,75 & 41 \\
\hline Gaziantep University & 124,9 & 111,77 & 23 \\
\hline Sakarya University & 122,24 & 109,85 & 0 \\
\hline Eskisehir Osmangazi University & 113,78 & 114,54 & 9 \\
\hline Tobb Ekonomi Ve Teknoloji University & 124,76 & 105,62 & 7 \\
\hline Inonu University & 112,05 & 113,98 & 20 \\
\hline Canakkale Onsekiz Mart University & 120,11 & 114,61 & 32 \\
\hline Kocaeli University & 113,75 & 118,05 & 0 \\
\hline Gaziosmanpasa University & 119,57 & 109,48 & 6 \\
\hline Anadolu University & 89,31 & 109,43 & 31 \\
\hline Yuzuncu Yil University & 110,87 & 108,95 & 10 \\
\hline Yeditepe University & 99,62 & 107,85 & 71 \\
\hline Pamukkale University & 114,72 & 108,23 & 3 \\
\hline Celal Bayar University & 116,01 & 104,35 & 0 \\
\hline Mersin University & 110,92 & 97,85 & 18 \\
\hline Abant Izzet Baysal University & 112,02 & 110,64 & 0 \\
\hline Cankaya University & 102,5 & 161,12 & 12 \\
\hline Duzce University & 107,09 & 110,11 & 0 \\
\hline Mustafa Kemal University & 115,26 & 109,27 & 4 \\
\hline Recep Tayyip Erdogan University & 106,84 & 109,81 & 4 \\
\hline Kahramanmaras Sutcu Imam University & 105,42 & 98,07 & 14 \\
\hline Acibadem University & 95,87 & 104,03 & 6 \\
\hline Afyon Kocatepe University & 108,25 & 108,42 & 13 \\
\hline Harran University & 101,89 & 105,67 & 6 \\
\hline Bulent Ecevit University & 101,29 & 104,78 & 4 \\
\hline Adnan Menderes University & 88,46 & 94,09 & 9 \\
\hline Kirikkale University & 98,51 & 85,58 & 3 \\
\hline Namik Kemal University & 96,44 & 83,01 & 7 \\
\hline Dumlupinar University & 93,95 & 106,42 & 5 \\
\hline Mugla Sitki Kocman University & 94,86 & 87,26 & 6 \\
\hline Nevsehir Haci Bektas Veli University & 102,21 & 112,89 & 3 \\
\hline Trakya University & 83,96 & 91,89 & 30 \\
\hline Necmettin Erbakan University & 95,03 & 68,99 & 10 \\
\hline Nigde University & 98,77 & 101,9 & 6 \\
\hline Balikesir University & 97,18 & 102,14 & 1 \\
\hline Cumhuriyet University & 98,44 & 117,32 & 11 \\
\hline Bahcesehir University & 84,41 & 100,43 & 39 \\
\hline Bozok University & 113,37 & 99,76 & 8 \\
\hline
\end{tabular}




\begin{tabular}{|c|c|c|c|}
\hline University & Article (1) & Citation (2) & $\begin{array}{c}\text { Foreign } \\
\text { Scholars (3) }\end{array}$ \\
\hline Turgut Ozal University & 95,68 & 49,32 & 9 \\
\hline Adiyaman University & 107,98 & 77,55 & 3 \\
\hline Kafkas University & 103,39 & 60,83 & 24 \\
\hline Istanbul Bilim University & 82,32 & 91,22 & 2 \\
\hline Sinop University & 90,79 & 91,88 & 2 \\
\hline Kadir Has University & 77,74 & 67,82 & 18 \\
\hline Aksaray University & 85,73 & 104,09 & 3 \\
\hline Erzincan University & 98,71 & 79,97 & 0 \\
\hline Hitit University & 90,12 & 75,48 & 9 \\
\hline Isik University & 72,32 & 85,35 & 19 \\
\hline Izmir Ekonomi University & 83,09 & 70,84 & 63 \\
\hline Galatasaray University & 41,4 & 71,96 & 5 \\
\hline Osmaniye Korkut Ata University & 78,24 & 92,92 & 0 \\
\hline Kastamonu University & 79,1 & 89,51 & 9 \\
\hline Karamanoglu Mehmetbey University & 85,97 & 101,52 & 3 \\
\hline Ahi Evran University & 81,89 & 79,75 & 3 \\
\hline Cag University & 131,49 & 68,18 & 21 \\
\hline Yalova University & 52,79 & 92,3 & 7 \\
\hline Bitlis Eren University & 82,19 & 83,01 & 2 \\
\hline Maltepe University & 39,13 & 57,88 & 11 \\
\hline Yasar University & 64,26 & 63,45 & 35 \\
\hline Cankiri Karatekin University & 65,44 & 82,42 & 5 \\
\hline Bartin University & 71,89 & 86,8 & 6 \\
\hline Mimar Sinan Guzel Sanatlar University & 57,23 & 23,9 & 1 \\
\hline Istanbul Kultur University & 49,55 & 69,45 & 1 \\
\hline Karabuk University & 68,24 & 69,93 & 0 \\
\hline Zirve University & 67,13 & 64,37 & 36 \\
\hline Amasya University & 86,21 & 74,52 & 0 \\
\hline Ordu University & 66,99 & 56,72 & 0 \\
\hline Gumushane University & 79,97 & 95,01 & 6 \\
\hline Istanbul Ticaret University & 41,75 & 50,77 & 5 \\
\hline Mehmet Akif Ersoy University & 71,85 & 52,86 & 1 \\
\hline Bilecik Seyh Edebali University & 73,82 & 70,19 & 0 \\
\hline Ufuk University & 49,4 & 85,49 & 0 \\
\hline Batman University & 68,27 & 62,91 & 2 \\
\hline Bingol University & 63,85 & 88,96 & 4 \\
\hline Okan University & 48,71 & 43,9 & 34 \\
\hline Istanbul Bilgi University & 52,87 & 46,18 & 63 \\
\hline Giresun University & 66,74 & 73,35 & 2 \\
\hline Siirt University & 61,28 & 85,02 & 7 \\
\hline Artvin Coruh University & 55,33 & 53,91 & 1 \\
\hline Izmir University & 79,96 & 43,59 & 4 \\
\hline Hakkari University & 58,77 & 76,59 & 4 \\
\hline Agri Ibrahim Cecen University & 44,34 & 103,08 & 0 \\
\hline Tunceli University & 58,99 & 53,36 & 0 \\
\hline Istanbul Aydin University & 43,85 & 29,36 & 0 \\
\hline Kirklareli University & 47,58 & 65,08 & 2 \\
\hline Usak University & 44,07 & 47,68 & 6 \\
\hline Istanbul Arel University & 39,87 & 29,03 & 4 \\
\hline Bayburt University & 54,64 & 81,5 & 5 \\
\hline Halic University & 16,46 & 31,77 & 3 \\
\hline Mus Alparslan University & 56,98 & 64,16 & 4 \\
\hline Gediz University & 34,15 & 43,12 & 12 \\
\hline Sirnak University & 6,64 & 100,87 & 9 \\
\hline Kilis 7 Aralik University & 46,2 & 48,6 & 3 \\
\hline Ardahan University & 20,97 & 28,6 & 0 \\
\hline Igdir University & 29,41 & 38,26 & 5 \\
\hline Mardin Artuklu University & 16,23 & 17,96 & 35 \\
\hline Kto Karatay University & 51,27 & 17,55 & 2 \\
\hline Beykent University & 32,42 & 38,2 & 7 \\
\hline Yeni Yuzyil University & 14,88 & 21,63 & 5 \\
\hline
\end{tabular}




\section{Appendix B}

Table B1. Tests of Normality

\begin{tabular}{lcccrrr}
\hline & \multicolumn{2}{c}{ Kolmogorov-Smirnov $^{\mathrm{a}}$} & \multicolumn{3}{c}{ Shapiro-Wilk } \\
& Statistic & df & Sig. & Statistic & df & \multicolumn{1}{c}{ Sig. } \\
Article &, 059 & 130 &, $200^{*}$ &, 986 & 130 &, 207 \\
Citation &, 052 & 130 &, $200^{*}$ &, 988 & 130 &, 312 \\
\hline
\end{tabular}

a. Lilliefors Significance Correction

*. This is a lower bound of the true significance.
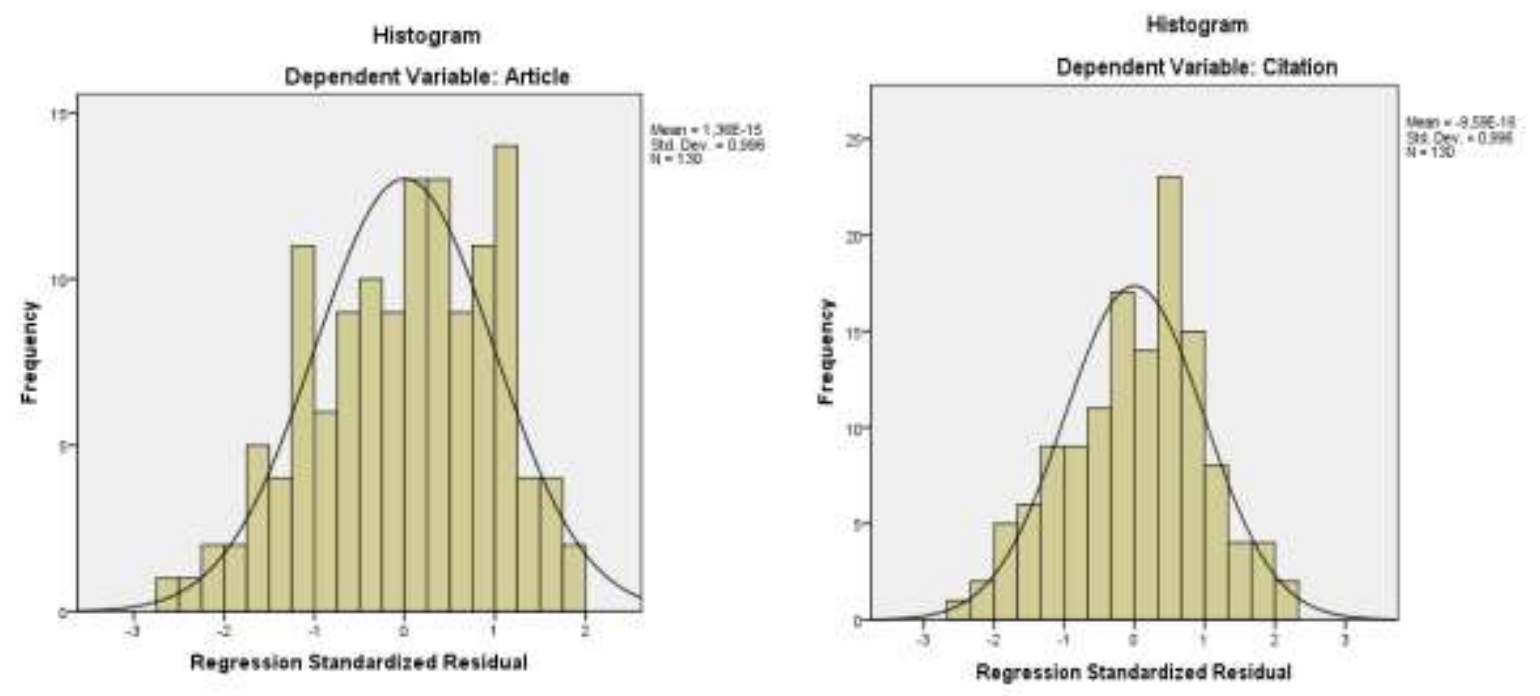

Figure B1. Histogram of the regression standardised residual
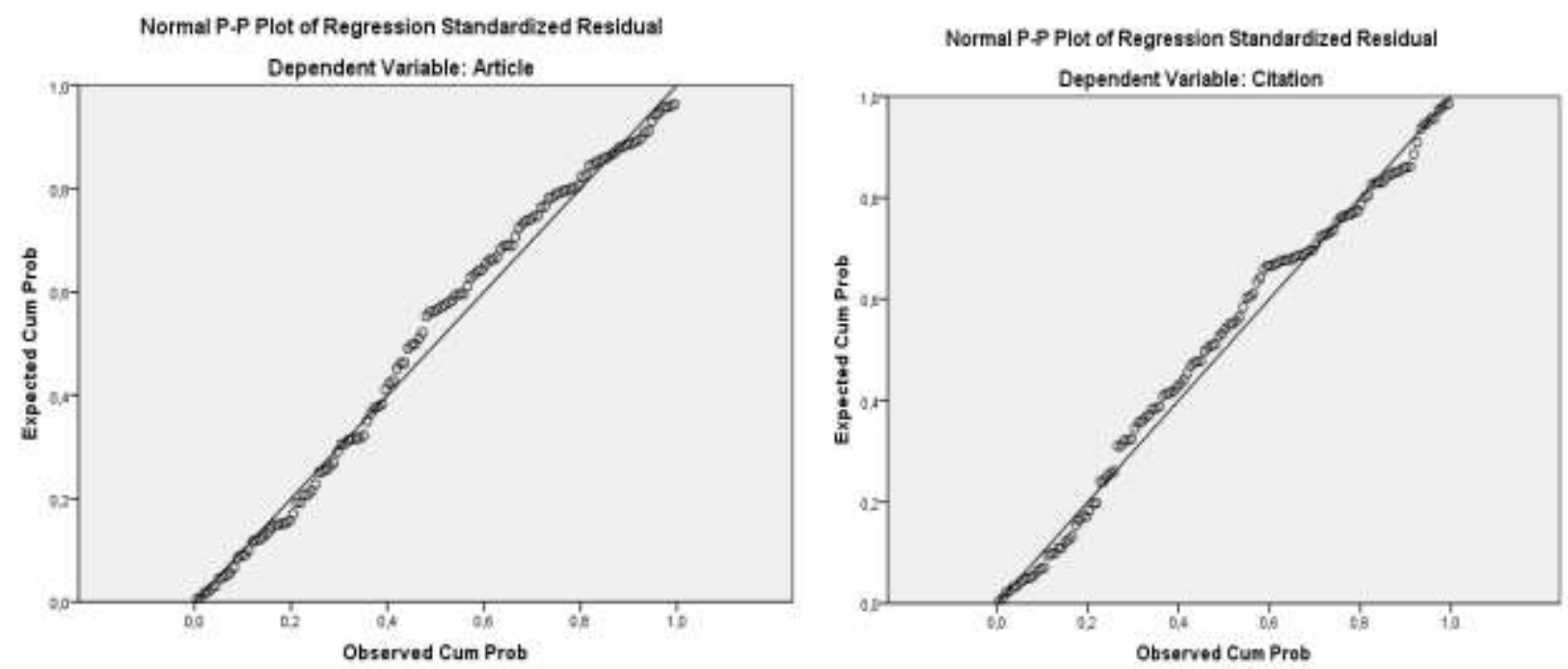

Figure B2. Normal P-P of the regression standardised residual

\section{Copyrights}

Copyright for this article is retained by the author(s), with first publication rights granted to the journal.

This is an open-access article distributed under the terms and conditions of the Creative Commons Attribution license (http://creativecommons.org/licenses/by/3.0/). 